\title{
Preliminary Notes towards a Soteriological Analysis of Museums
}

Notes préliminaires pour une analyse sotériologique des musées

\section{Klas Grinell}

\section{(2) OpenEdition}

\section{Journals}

Electronic version

URL: http://journals.openedition.org/iss/1666

DOI: $10.4000 /$ iss. 1666

ISSN: 2306-4161

Publisher

ICOM - International Council of Museums

\section{Printed version}

Date of publication: 12 October 2019

Number of pages: 123-137

ISBN: 978-92-9012-467-2

ISSN: 2309-1290

Electronic reference

Klas Grinell, «Preliminary Notes towards a Soteriological Analysis of Museums », ICOFOM Study Series [Online], 47(1-2) | 2019, Online since 12 October 2019, connection on 24 October 2019. URL : http:// journals.openedition.org/iss/1666 ; DOI : 10.4000/iss.1666 


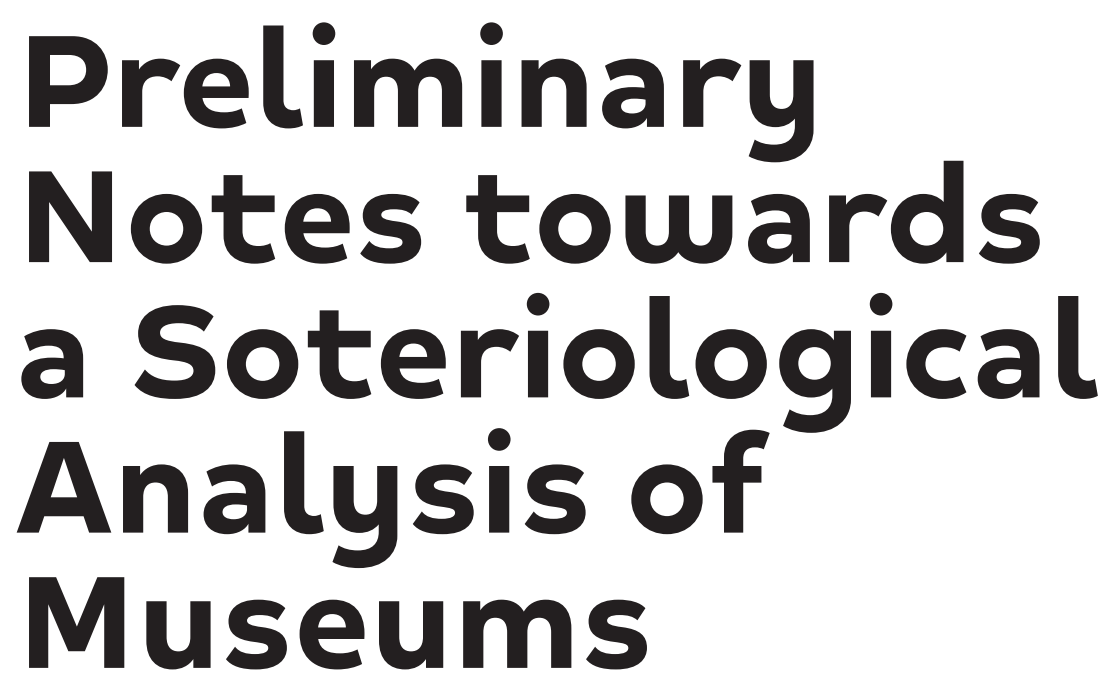

\section{Klas Grinell}

University of Gothenburg, Sweden.

This article investigates the potentials of the concept of soteriology in museology. It is claimed that modern museum politics and policy can be analyzed as a soteriology built around the idea that culture is a means to promote peace, and that it can offer salvation from the inhumane horrors of World War II. The UN in general, and UNESCO in particular, played key roles as soteriological institutions after WWII, akin to that of the modern nation-state in the Westphalian order after the so-called Wars of Religion of the $17^{\text {th }}$ century. The soteriological element in the nation-state is the nation, in UNESCO it is culture and heritage. Building on this as a premise the text explores the museological potentials of the concept of soteriology.

Key words: soteriology, museology, UNESCO, culture, heritage 


\section{R'́SUMÉ}

\section{Notes préliminaires pour une analyse sotériologique des musées}

Cet article étudie les potentialités du concept de sotériologie en muséologie. On prétend que la politique et les règles des musées modernes peuvent être analysées comme une sotériologie construite autour de l'idée que la culture est un moyen de promouvoir la paix et qu'elle peut permettre de sauver des horreurs inhumaines de la Seconde Guerre mondiale. L'ONU en général, et l'UNESCO en particulier, ont joué un rôle clé en tant qu'institutions sotériologiques après la Seconde Guerre mondiale, semblables à celles de l'État-nation moderne dans l'ordre westphalien après les prétendues guerres de religion du XVII siècle. L'élément sotériologique dans l'État-nation est la nation, à l'UNESCO c'est la culture et le patrimoine. S'appuyant sur cette prémisse, le texte explore les potentiels muséologiques du concept de sotériologie.

Mots clé: sotériologie, muséologie, UNESCO, culture, patrimoine

\section{丈}

This article explores the analytical potentials of the concept of soteriology. It is argued that modern museum politics and policy can be understood as a soteriology built around the UNESCO-idea that culture can create peace, and thereby offers a road to salvation from the inhumane horrors of World War II. The aim is to show that this might be a fruitful perspective worthy of empirical trial, and to see where it could be applied. More on museums, culture and heritage later, first the concept of soteriology must be introduced.

\section{Soteriology}

The topic of religion in museums has, as the recent handbook Religion in museums argues, been surprisingly understudied (Promey, 20I7). In only one of the one hundred articles in the four volume International Handbooks of Museum Studies series is there any explicit discussion of religion (Macdonald \& Rees Leahy, 2015), consisting of a discussion on the treatment of possible sacredness of Orthodox icons (Gaskell, 20I5, pp. I7I-I75). On a vaguer and un-indexed level there is however some instances of comparisons or similes made between museums and religious buildings and ritual behavior (Barnaby, 2015, Biehl-Missal \& vom Lehn, 2015, Brown \& Peers, 2015, Kramer, 2015). At least since Goethe's visit to the Dresden Art gallery in March I768 it has been popular to compare the Museum to a Holy place where one goes to venerate art (Offe, 2004, p. II9). This kind of analysis has also been expanded to include the ritualized uses of history in national museums (Bräunlein, 2004, p. 32). This topic, however, I 
leave to other writers in this volume. It should be noted that the soteriological analysis of museums explored here have little to do with religion.

Soteriology is a theological and religious studies concept that refers to a 'theory or doctrine of salvation'. The world we live in is seen as "distorted, self-destructive, or failing to reach its true potential". Soteriology asserts that this potential can be fulfilled and that individuals and social groups can be made "whole" (Fiddes 2007, p. I76). In its Christian, and possibly pan-Abrahamitic, version salvation implies that human sin has created "a breach between the creator and the created" (Fiddes, 2007, p. I77). As an analytical concept soteriology centers on the promise of fulfillment. It is forward-looking and does not require any real explication of how the fulfillment can or will be reached. It is more of a belief and hope than a road-map or elaborate ideal, which also sets it apart from similar concepts such as ideology and utopia: ideology being more centered on the solutions and utopia on the fulfilled world (Ricoeur, , I986).

Salvation is often presented as a tripartite concept. It can be related to I) grace, "the idea that salvation occurs less through human effort and more due to a higher power"; 2) effort, "the idea that salvation occurs through human effort to overcome ignorance and/or sin"; and 3) ritual; "the idea that certain practices or sequences of action have an automatic efficacy independent of human or divine intention" (Flood, 2016, p. 624).

Salvation is here seen as an individual phenomenon, or maybe a common human affair. Salvation is something that can happen to humans. The influential Protestant theologian Paul Tillich (1967, p. 247) emphasized that in early Christendom salvation (Erlösung) was instead understood as a cosmic affair. The Greek soteria is connected to the root soas, and the Latin salvatio to salvus. Both words are connected to the concept of 'whole', as is the English 'holy'. Salvation can thus be taken to mean that the entire world is made whole and righteous. For example Marcus Borg (2008) argues that the Kingdom of God referred to in the Gospels was understood as a promise of worldly and political justice. A similar division can be made in soteriologies of culture between a liberal-conservative emphasis on individual salivatory formation (Bildung), and socialist emphasis on culture as a means for societal transformation (Snickars, 200I).

\section{Museology of the sacred}

The more theistic an understanding of salvation the more probable it is that the idea of grace is prominent, as can be seen in the Abrahamitic faiths (Judaism, Christianity, Islam) as well as some forms of Indian religiosity (Flood, 20I6, p. 624). Some of the strongest doctrines of salvation solely due to the grace of a higher power can be found in Christian Protestantism (King, 1999, p. 62, Dubuisson, 2003, Harvey, 2013).

The tripartition of salvation is an analytical distinction. In most real life situations, the soteriological beliefs and doctrines include all three aspects. If we 
turn to the second interpretation of salvation as the effect of human efforts to overcome ignorance this seems applicable to many discourses on culture. In much of the formulations legitimizing the growth of the museum sector the museum was heralded as an institution where the common people could be inspired to work to become cultured (Bennett, 1995, Minucciani, 2013). What Sharon Macdonald (2005) has described as:

\begin{abstract}
The 'established church' of the museum world is surely the nineteenth-century public museum - that confident expression of, especially, nation state identity, of the worthiness of public learning, of progress and the achievements of science and the arts, and of the ambition of civil society itself (p. 213).
\end{abstract}

Here we can also see some aspects that could be interpreted as deliverers of grace in return for identification and loyalty, without any specific civilizing effort required from the individual: the nation state and civil society could be interpreted as higher powers with agency. But in order to gain access to the world of progress and achievements one also needs to show some ambition to learn and become worthy - to make an effort.

The cultivating role of the museum institution also ties closely to the idea of salvation via ritual. Most of the existing museological literature that could be described as relating to soteriological perspectives most explicitly talks about the museum visit as a ritual, even if the experience of the ritual often is described as a way to overcome ignorance (Duncan, 1995, Bräunlein, 2004, Bouquet \& Porto, 2005, Mairesse, 2014).

The museum has repeatedly been interpreted in analogue with religious sites, religious rituals and religious experience (Macdonald, 2005, Britton, 20I7). The ritual of the museum visit can be described as stemming from a Protestant understanding of transcendence that by the German Romantics was transferred from the Church to the Art collection (Bräunlein, 2004, pp. 20-2I, Klotz, 2000). Most writers discussing museums as places for ritual and salvific blessings have concentrated on art museums (Duncan, 1995). This might explain why there is little focus on the role of the visitors' effort to overcome ignorance. The visitors have been more prominent in museums literature building on Foucauldian perspectives of power and discipline. The road to salvation lies in being a disciplined and governable modern subject (Bennett, 1995, Hooper-Greenhill, I992, Bennett, 2015).

\title{
A soteriology of culture
}

The analytical fruitfulness of soteriological perspectives needs to be empirically tested on actual policies and politics of culture and museum, for example on 
UNESCO's soteriology of culture. Building on preliminary analysis presented earlier (Grinell, 20I8) the terms 'culture' and 'heritage' are claimed to have soteriological qualities and functions in UNESCO discourse. Museums are the venues for these salvific efforts and rituals and ICOM could in turn be interpreted as a clergy for UNESCO's soteriology. The ICOFOM could accordingly be called the theologians of the field.

Despite its Christian origin soteriological analysis is not an exclusively Christian subject. According to Mohammad Hassan Khalil (20I2) "salvation is arguably the major theme of the Qur'an” (p. 2). Marcus J. Borg (20II) stresses that salvation in Jewish and early Christian settings was not understood as referring to an afterlife. He suggests transformation as a better English equivalent for salvation and talks about it as being about individual change and healing, as well as the coming of an immanent world of justice. Similarly, Mohammed Rustom (2018) has argued that it is Christocentric to translate the Qur'anic concepts formed from the roots "n-j-w ('to deliver, set free'), h-y-ș ('to flee, escape'), r-w-h ('to comfort'), and n-q-dh ('to rescue')" into a single and Christian tainted concept of salvation (Rustom, p. 362, Borrmans, 2006). As argued here salvation is not necessarily a religious concept. For the purpose of this article I propose a more general understanding of soteriology as referring to theories of salvation, deliverance or 'making whole'.

Such a broad understanding of salvation lies behind Robert H. Nelson's seminal Reaching for heaven on Earth: The theological meanings of economics (I99I) where modern economics is analyzed as a "system of thought that is a source of fundamental meaning and purpose" (p. xxv). Underlying his history of economics is a thesis that "the medieval path to salvation has become the modern path to economic progress" (Nelson, I99I, p. I2I). It is precisely this that makes it relevant to talk about modern economics as a soteriology. In modern liberal democracies economic progress is the prime social goal. The fact that this goal is treated as inherently good is what makes it a soteriological concept, even if we find it more difficult to name one prime modern social goal. Economic progress could also be described more as a means than an end.

Especially in modern welfare states salvation is also tied to a future justice. As in all soteriologies modern, secular salvation is presented as a future hope, a possible world where violence, poverty and division are overcome. The world of justice promised by the modern welfare state is always a possible ideal and a possible way of behaving towards others. The laws and policies designed to create salvation can never be proven to be just. In the imperfect present they can at best be legitimate. In the words of Jacques Derrida (1992), justice in this world can never be more than a promise and a hope. He therefore speaks of justice as "a messianic hope" that will always be unfulfilled in this world. True justice is a soteriological promise beyond the reach of philosophy, jurisprudence or empirical investigation. 
One concrete way to decide if a concept is soteriological or not is therefore to ask if its goals can be reached via institutional structures or if they are more of messianic hopes. UNESCO is interesting in this respect since it is a political institution without power to enforce its conventions or recommendations. The difference between a convention and a law is that a law needs to be enforced to have legitimacy and relevance, while a convention is more of an expression of hope and intention.

It might even be argued that the impossibility of worldly justice explains the need for soteriology good (Derrida, I982, Caputo, I997). But a museological analysis of soteriology does not need to ground itself in an ontological position. It can instead look at the function of soteriology. Soteriological concepts such as salvation, progress, justice, 'culture for peace' share a certain vagueness that is central to their functionality. In order to rally believers, the soteriological promise must be kept as open as possible. Vagueness is functional (Grinell, 2015, pp. I89-I9I). The attraction of the soteriological concepts 'culture' and 'heritage' in politics and policy can be explained, then, through their open mobilizing power.

Using the language of critical discourse analysis (CDA), a soteriological concept can be described as a floating signifier whose strength lies in its ability to be attached to different chains of references according to different political and spiritual aims. There is no direct link between the signifier and a particular signified goal, the signifier instead gets its meaning in relation to other signifiers in a certain discourse and ideology within which it is given a specific meaning. In CDA that meaning is seen as ideological. In ideology the aim is to show that one's own understanding of the signifier is the only possible one and thereby achieve political hegemony (Laclau \& Mouffe, I985, Fairclough, 1995). From a soteriological perspective, however, the power of the floating signifier is rather that it can function as a promise for people with different and even competing ideologies, as well as for nations with differing views on democracy and governance.

Depending on how the promise is formulated there are always limits to whom the soteriological promise includes. This means that a tripartition of the concept of salvation that analyses soteriologies as exclusivist, inclusivist or pluralist is more relevant for the needs and purposes of a museological concept of soteriology (Khourchide, 2015).

- a) An exclusivist soteriology holds that only its own particular path leads to salvation. All other roads lead astray (to Hell or rebirth or other kinds of failure). This position is clearly stated in the Gospel of John (I4.6): "I am the way, and the truth, and the life; no one comes to the Father, but by me" and especially its explication and application in the Roman Catholic dogma Ecclesiam nulla salis (No salvation outside the Church) (Race, I983, p. Io). It is also found in the Qur'an 3:85 "If anyone seeks a 
religion other than istām, it will not be accepted from him: he will be one of the losers in the hereafter" (Khalil, 2002, p. 9).

- b) inclusivist soteriology means believing that its particular path leads to salvation, but in difference to exlusivists inclusivists "hold that sincere outsiders who could not have recognized it as such will be saved" (Khalil, 2002, p. 8). This is expressed in Acts I4:I6 "In past generations he allowed all the nations to walk in their own ways", as well as in the Qur'an 17:15 "We do not punish until We have sent a messenger".

- c) pluralist soteriology holds that there are several paths that can lead to salvation (Race 1983). This can be exemplified by Acts io:35 "Truly I perceive that God shows no partiality, but in every nation any one who fears him and does what is right is acceptable to him" or the Qur'an 5:48: "We have assigned a law and a path to each of you. If God had so willed, He would have made you one community, but He wanted to test you through that which He has given you, so race to do good: you will all return to God and He will make clear to you the matters about which you differed." Museums have moved from an inclusivist to a pluralist soteriology, as we shall see later.

\section{UNESCO as a soteriological institution}

According to theologian William Cavanaugh "the modern [Westphalian] state is built upon a soteriology of rescue from violence" (2002, p. 2). By swearing loyalty to the nation the citizens of Europe should be salvaged from violence. This de-positioning of the Church and the construction of the Nation-state as the all-encompassing and all-responsible power gave birth to a secular soteriology which eventually found its shape in Enlightenment liberalism built on individualism and rational choice. Thereby other communal associations were made politically redundant as state law was formulated to regulate matters of kinship, property and inheritance. In return for individual loyalty the nationstate promised to save the citizens from violence, by imposing a monopoly on violence (Cavanaugh, 2002, p. 55). As seen, the modern liberal nation-state also promised welfare, justice and economic progress. The most relevant overarching soteriological concept for an analysis of the modern nation-state is therefore 'the nation' (Aronsson, 2015).

The first half of the $2 \mathrm{O}^{\text {th }}$ century made it all too clear that national enlightened values and economic progress did not hinder the use of violence, not even within Europe. The soteriological promise of citizenship was overridden by ideas of exclusive and mythical nationalism. A new universal soteriology was needed. It promoted culture as the key to peaceful minds.

The UNESCO charter (I945) opens with a credo: "since wars begin in the minds of men, it is in the minds of men that the defenses of peace must be constructed." To realize this Kingdom of Peace "the world's inheritance of books, works of art and monuments of history and science" must be conserved and protected, 
and displayed by museums for the use in salvific efforts and rituals. This is the core of the soteriology of heritage. It can be noted that there is no argument to connect the two quotes. The first statement might be empirically correct, but doesn't say anything about how a peaceful mind can be constructed. This is why it is relevant to talk about a UNESCO soteriology.

The United Nations and UNESCO continued the Modern trajectory of disregard for social groups and associations. Liberal individualism remained as a frame for an inter-national effort to construct individual minds that respected the nation-states' monopoly on violence. The solution is in the hands of beneficent rulers.

\section{From inclusivism to pluralism}

The United Nations is made up of modern nation-states. UNESCO is one of its I6 specialized agencies (Singh, 20II). The nations of the world came together in UNESCO to express their belief that culture was the road towards international understanding and global peace (UNESCO, I945, § XVII). UNESCO promoted a secular and universal culture expressed mainly in the canonical high art of the Western civilization (Hill, I953, UNESCO, 1954, Salles, 1956). This was an adaptation of the sacralisation of art that has its roots in European Enlightenment and Romanticism.

In the 1950s, 6os and early 70s culture was mostly used within UNESCO as a universal. Through our joint appreciation of culture and art we can understand the humanity of each other globally (UNESCO, I966, Maheu, 1973, Maheu, 1974). In the late ig6os many things changed. A critique of the inherent elitism in UNESCO's idea of culture grew, related to the rise of youth and popular culture in the emerging consumer societies mainly in the West. Decolonization expanded the constituency of UNESCO. Many non-Western cultures that had had no place in UNESCO now called for appreciation and recognition (Maheu, 1973). The concept of culture thus became more anthropological and nationalized. ICOM began high-lighting that museums are institutions in the service of society and its development (ICOM, 1974, Valderrama, I995, Davis, 2008). In this process the earlier inclusivist position was changing into a pluralist one. As often in UNESCO 'cultural values' was left undefined in order to avoid political tension (Wong, 2008). The program report Cultural rights as human rights introduced the need to respect the culture of minorities, and argued that all larger states contain some kind of minority (Gellner, 1970, Maheu, 1973). The call for international understanding slowly transformed into a call for intercultural dialogue (UNESCO, 1972, Harrison 2013, pp. 76-84).

In the early 1990 a new theology of diversity was introduced, supplanting the earlier UNESCO orthodoxy of one universal and shared culture. Rituals were redirected towards inter-cultural dialogue and post-national identity making (UNESCO, I995, 2002). Was it possible to create a reformed but still inclusivist theory of diversity, or was this a reformation producing pluralist 
soteriologies in breakaway movements such as new museology, ecomuseums and post-museums (Vergo, 1989, Davies, 20II, Hooper-Greenhill, 2000)?

The 1995 report Our creative diversity holds a conflict between an inclusivist, universal and romantic soteriology of culture and a pluralist, multicultural and anthropological one. The report contains opaque salvific proclamations like: "Let us rejoice in diversity, while maintaining absolute standards of judging what is right, good and true" (UNESCO, I995, p. 55). The pluralist focus on diversity led to an ethnification of heritage and cultural identity and the rise of inter-cultural dialogue, but did not erase the absolute standards of the older inclusivist and more self-assertive soteriological belief that culture can produce international understanding and thus peace.

UNESCOs interest in intercultural understanding coincides with a similar focus within the International council of Museums (ICOM). At the Quebec General Conference of ICOM in October 1992 the Advisory Committee recommended the establishment of a working group that should address "cross-cultural issues impacting on museums". Later that year the ICOM Executive Council established a Working Group on Cross Cultural Issues (WGCCI). Its mission was to charter how museums around the world addressed "the wide range of issues with cross cultural dimensions" also to formulate guidelines on how "museums should endeavor to deal with cultural diversity in general and indigenous and multicultural issues in particular" as well as "the ways that cross-cultural perspectives should be reflected in the work of ICOM and its committees." (ICOM, 1997).

In the r99os the cultures implied in the inter-cultural and multi-cultural perspectives were national and/or ethnic cultures. It was not until 2009 that the UN announced a year of interfaith cooperation. Religious dialogue has a longer institutional genealogy with the first Parliament of the World's religions held in Chicago in I893. This did not really lead to any broader movement, and apart from a Japanese initiative in the r930s it wasn't picked up again until the Ioo-year anniversary gathering in the same city (Swidler, 2013). There were other trajectories as well. The Christian Churches started to open for dialogue in the 1950 inspired by the same context that gave rise to UNESCOs efforts for international understanding. For the Catholic Church the second Vatican council in rg6os was a major shift that also led to that the World Council of Churches developed a program for dialogue in the I970s. In the coming year they also formed contacts with different Muslim organizations and institutions and a field of inter-faith dialogue started to grow. Muslim interest in inter-religious dialogue have a historical predecessor in the Mughal period in India, and with the first generation modernists in the colonial period, thinkers like al-Tathawi, Muhammad Abduh, al-Afghani, Namik Kemal and Said Nursi (Grinell, 2016). 


\section{Understanding pluralistic soteriologies}

Everything points to the sense that pluralistic ideals has gained a sort of hegemony in international cultural heritage institutions. It might therefore be needed to probe a little bit deeper into pluralism. One way of addressing plurality has been through the concept of multiple modernities. It has been argued that there is a difference between a plurality of paths and an idea of multiple modernities that goes beyond the idea of a common destination, a focus on different cultures rather than different experiences within a common broad modernity (Wagner, 2008). I would argue, though, that a soteriological analysis is only fruitful when there is an idea of a common destination, a shared idea about salvation.

It has been argued that we all share a constant need to find meaning and some sense of certainty and community. Such a universal predicament calls upon us to choose a path for what Tariq Ramadan calls "our quest for meaning". As a response to this need there is always a plurality and diversity of paths. Universality in the modern/secular world lies in "the common space to which the different paths lead" (Ramadan, 20I0, p. 24). This space is not necessarily a coherent and cohesive social imaginary, like the exclusivist ideal modern Bürgerlische Öffentlichkeit theorized by Habermas (1962), but "the spaces of intersection where we can meet on equal terms [...], the intersection of what we have in common, rather than the integration of differences" (Ramadan, 20IO, p. 24). Charles Taylor has similarly described his work as an effort to open a space for conversations where "we eschew mutual caricature and try to understand what 'fullness' means for the other." (2010, р. 3г8).

In socialist understandings of society, power and antagonism are seen as constitutive of social relations. There is no alternative order where antagonism can be evaded; soteriological imaginings that the world can be made whole will inevitably lead to the exclusion of those who cannot be included in the imagined community. Instead of resting on an inclusivist assumption of the common good this agonistic pluralism works from an understanding of a pluralistic and conflictual consensus that will not expect everyone to have similar ideals but will demand respect for those with other soteriological imaginaries as legitimate adversaries within the democratic community (Mouffe, 2000). One possible gain of a more elaborate concept of pluralistic soteriology therefore lies in overcoming this divide and creating an opening for some sort of antagonistic tolerance or reconciliation (Hayden, 2013).

\section{Concluding remarks}

The renewed interest in the sacred addressed in this book is one aspect of the paradigm shifts of the I980s (Casanova, 1994). From a soteriological perspective this can be interpreted as an unresolved shift from an inclusivist to a pluralist position. It is in this tension between different soteriologies that the concept of heritage gained currency as a less burdened signifier and carrier of hopes. 
Heritagization can thus be described as taking cultural inheritance from its exclusive national specificities and marking it as heritage, as something beneficial for 'humankind'.

I have argued UNESCO and ICOM could be described as soteriological institutions that index the canon through which salvation can be gained, that they are effects of an ongoing centralization of power that could be interpreted as inclusivist. At the same time, these institutions have developed a strong commitment to pluralistic and intercultural values. These claims of course needs further empirical testing.

Existing uses of soteriology have been shown to have too broad an understanding of pluralism for immediate museological application. Still, it has, hopefully, been shown that soteriology presents an interesting and fruitful perspective for museological analysis. Maybe the museological unease with religion and the sacred can be described as an expression of the classically inclusivist position of UNESCO/ICOM? As this is only a first preliminary formulation of a soteriological analysis of museums there is a need for further development and trials before such questions can be answered convincingly.

\section{References}

Aronsson, P. (2015). National museums as cultural constitutions. In P. Aronsson \& G. Elgenius (Eds.). National museums and nation-building in Europe 1750-2010: mobilization and legitimacy, continuity and change (pp. 167-199). London: Routledge.

Barnaby, A. (2015). Lightning Practices in Art Galleries and Exhibition Spaces, 1750-I850. In M. Henning (Ed.), The International handbook of museum studies. Museum Media (pp. I9I-2I4). London: Wiley-Blackwell.

Bennett, T. (1995). The Birth of the Museum: History, Theory, Politics. London: Routledge.

Biel-Missal, B., \& vom Lehn, D. (20I5). Aesthetics and Atmosphere in Museums: A Critical Marketing Perspective. In M. Henning (Ed.), The International handbook of museum studies. Museum Media (pp. 235-258). London: Wiley-Blackwell.

Borg, M. J. (2008). Jesus: The life, teachings and relevance of a religious revolutionary, New York: HarperOne.

Borg, M. J. (20II). Speaking Christian: Recovering the lost meaning of Christian words, London: SPCK Publishing.

Borrmans, M. (2006). Salvation. In J. D. McAuliffe (Ed.), Encyclopaedia of the Qur'ān. (vol 4, p. 522). Leiden: Brill. 
Bouquet, M., \& Porto, N. (Eds.). (2005). Science, Magic and Religion: The Ritual Processes of Museum Magic. New York/Oxford: Berghahn Books.

Bräunlein, P. (2004). Zurück zu den Sachen! - Religionswissenschaft vor dem Objekt: Zur Einleitung. In P. Bräunlein (Ed.), Religion und Museum: Zur visuellen Repräsentation von Religion/en im öffentlichen Raum (pp. 7-54). Bielefeld: Transcript Verlag.

Britton, K. C. (20I7). Toward a theology of the art museum. In G. Buggeln, C., Paine \& S. B. Plate (Eds.), Religion in museums: Global and multidisciplinary perspectives (pp. 2I-28). London: Bloomsbury.

Brown, A. K., \& Peers, L. (2015). The Blackfoot Shirt Project: "Our Ancestors Have Come to Visit". In A. E. Coombes \& R. B. Phillips (Eds.), The International handbook of museum studies. Museum transformations (pp. 263-288). London: Wiley-Blackwell.

Caputo, J. (I997). The Prayers and Tears of Jacques Derrida. Bloomington: Indiana University Press.

Casanova, J. (1994). Public religions in the modern world. Chicago: University of Chicago Press.

Cavanaugh, W. T. (2002). Theopolitical imagination: Discovering the liturgy as a political act in an age of global consumerism. London: T\&T Clark.

Davies, P. (20II). Ecomuseums: A sense of place. London: Continuum.

Derrida, J. (I982). Différance. In J. Derrida, Margins of Philosophy (pp. I-28). Chicago: Chicago University Press.

Derrida, J. (1992). Force of Law: The 'mystical foundation of authority'. In D. Cornell, M. Rosenfeld \& D. G. Carlson (Eds.), Deconstruction and the possibility of Justice (pp. 3-63). NewYork/London: Routledge.

Dubuisson, D. (2003). The Western Construction of Religion: Myths, knowledge and ideology. Baltimore: John Hopkins University Press.

Duncan, C. (I995). Civilizing rituals: Inside public art museums. London/New York: Routledge.

Fairclough, N. (1995). Critical Discourse Analysis: The Critical Study of Language. Essex: Pearson Education Limited.

Fiddes, P. F. (2007). Salvation. In J. Webster, K. Tanner \& I. Torrance (Eds.), The Oxford Handbook of Systematic Theology (pp. 176-196). Oxford: Oxford University Press.

Flood, G. (2016). Salvation. In M. Stausberg \& S. Engler (Eds.), The Oxford handbook of the study of religion (pp. 623-634). Oxford: Oxford University Press. 
Gaskell, I. (2015). The Life of Things. In M. Henning (Ed.), The International handbook of museum studies. Museum Media (pp. I67-190). London: WileyBlackwell.

Gellner, E. (Ed.). (I970). Cultural rights as human rights. Paris: Unesco.

Grinell, K. (2015). Reflections on Reason, Religion and Tolerance: Engaging with the ideas of Fetullah Gülen. New York: Blue Dome Press.

Grinell, K. (2016). Islams filosofihistoria: Från Fitaguras och Aflatun till Nasr och Ramadan. Stockholm: Molin \& Sorgenfrei.

Habermas, J. (1962). Strukturwandlungen der Öffentlichkeit: Untersuchungen zu einer Kategorie der bürgerlichen Gesellschaft. Darmstadt: Luchterhand Verlag.

Harrison, R. (2013). Heritage: Critical approaches. London: Routledge.

Harvey, G. (2013). Food, sex and strangers. Understanding religion as everyday life. Durham: Acumen.

Hayden, R. M. (2013). Intersecting Religioscapes and Antagonistic Tolerance: Trajectories of Competition and Sharing of Religious Spaces in the Balkans. Space and Polity, 23(3), pp. 320-34.

Hill, C. P. (1953). Suggestions on the teaching of history. Paris: UNESCO.

Hooper-Greenhill, E. (1992). Museums and the Shaping of Knowledge. London: Routledge.

Hooper-Greenhill, E. (2000). Museums and the Interpretation of Visual Culture. London: Routledge.

ICOM. (I974). Resolutions adopted by the $11^{\text {th }}$ General assembly of ICOM in Copenhagen, June I4.

ICOM. (I997). Report of the Working Group on Cross Cultural Issues of the International Council of Museums: Presented at the $89^{\text {th }}$ session of the Executive Council of ICOM on December 1997.

Khalil, M. H. (2012). Islam and the Fate of Others: The Salvation Question. Oxford: Oxford University Press.

Khourchide, M. (2015). Die theologischen Grundlagen des christlich-islamischen Dialogs aus Sicht der islamischen Theologie. In M. Rohe, M. Khorchide, H. Engin, H. Schmid, Ö. Özsoy \& H. Schmid (Eds.), Christentum und Islam in Deutschland: Grundlagen, Perspektiven und Erfahrungen des Zusammenlebens (pp. 579-605). Freiburg: Herder Verlag.

King, R. (I999). Orientalism and Religion: post-colonial theory, India and the mystic East. New York: Routledge.

Klotz, H. (2000). Geschichte der Deutschen Kunst. Bd. 3: Neuzeit und Moderne.1750-20oo. München: C.H. Beck. 
Kramer, J. (2015). Möbius Museology: Curating and Critiquing the Multiversity Galleries at the Museum of Anthropology at the University of British Columbia. In A. E. Coombes \& R. B. Phillips (Eds.), The International handbook of museum studies. Museum transformations. (pp. 489-510). London: Wiley-Blackwell.

Laclau, E., \& Mouffe, C. (I985). Hegemony and socialist strategy: Towards a Radical Democratic Politics. London: Verso.

Latour, B. (2005). Reassembling the social: an introduction to Actor-network-theory, Oxford: Oxford University Press.

Macdonald, S. (2005). Enchantment and its dilemmas: the Museum as a ritual site. In M. Bouquet \& N. Porto (Eds.), Science, Magic and Religion: The Ritual Processes of Museum Magic (pp. 209-228). New York/Oxford: Berghahn Books.

Macdonald, S., \& Rees Leahy, H. (Eds.). (2015). The International handbook of museum studies, vol I-IV. London: Wiley-Blackwell.

Maheu, R. (I973). Culture in the contemporary world: Problems and prospects. Paris: UNESCO.

Maheu, R. (1974). UNESCO in perspective. Paris: UNESCO.

Mairesse, F. (2014). Le culte des Musées. Brussels: Académie royale de Belgique.

Minucciani, V. (Ed.). (2013). Religions and Museums in Europe: Immaterial and material heritage. Torino: Umberto Allemandi \& Co.

Mouffe, C. (200o). The Democratic Paradox. London: Verso.

Nelson, R. H. (I99I). Reaching for heaven on Earth: The theological meanings of economics. Lanham: Rowman \& Littlefield.

Nelson, R. H. (20I4). Economics as religion: From Samuelson to Chicago and Beyond. Philadelphia: Pennsylvania University Press.

Offe, S. (2004). Museen. Tempel. Opfer. In P. Bräunlein (Ed.), Religion und Museum: Zur visuellen Repräsentation von Religion/en im öffentlichen Raum (pp. II9-I38). Bielefeld: Transcript Verlag.

Promey, S. M. (2017). Foreword: Museums, religion and notions of modernity. In G. Buggeln, C. Paine \& S. B. Plate (Eds.), Religion in museums: Global and multidisciplinary perspectives (pp. vix-xxv). London: Bloomsbury.

Race, A. (1983). Christians and Religious Pluralism: Patterns in the Christian Theology of Religions. London: SCM Press.

Ramadan, T. (2010). The Quest for Meaning: Developing a Philosophy of Pluralism. London: Penguin. 
Ricoeur, P. (1986). Lectures on ideology and utopia. New York: Columbia University Press.

Rustom, M. (2018). Notes on the Semantic Range of 'Deliverance' in the Quran. Journal of the American Oriental Society, I38(2), 36I-367.

Salles, G. (1956). UNESCO's tenth anniversary: a review of its work for museums, sites and monuments. Museum International, 9(3), pp. I34-I43.

Singh, J. P. (20II). United Nations Educational, Scientific and Cultural Organization (UNESCO): Creating norms for a complex world. London: Routledge.

Snickars, F. (Ed.) (200I). Culture, society and market: The Swedish research seminar held at Sigtuna, January 24-25 2000. Stockholm.

Swidler, L. (2013). The History of Inter-Religious Dialogue. In C. Cornille (Ed.), The Wiley-Blackwell Companion to Inter-Religious Dialogue (pp. 3-I9). Oxford: Wiley-Blackwell.

Taylor, C. (20I0). Afterword: Apologia pro Libro sui. In M. Warner, J. VanAntwerpen \& C. Calhoun (Eds.), Varieties of secularism in a secular age (pp. 300-324). Cambridge, MA: Harvard University Press.

Tillich, P. (I967). Die religiöse Substanz der Kultur: Schriften zur Theologie der Kultur, Gesammelte Werke IX. Stuttgart: Evangelischen Verlagswerk.

UNESCO. (1945). Constitution of the United Nations Educational, Scientific and Cultural Oganization: Adopted in London November I6, I945. Paris: UNESCO.

UNESCO. (I954). UNESCO and its programme X: Arts and letters. Paris: UNESCO.

UNESCO. (1966). Twenty years of service to peace 1946-1966. Paris: UNESCO.

UNESCO. (1972). Recommendations concerning the protection, at national level, of the cultural and national heritage. Paris: UNESCO.

UNESCO. (I995). Our creative diversity: Report of the World commission on culture and development. Paris: UNESCO.

UNESCO. (2002). UNESCO Universal declaration on cultural diversity: Adopted by the $3 \mathrm{I}^{\mathrm{st}}$ session of the General conference of UNESCO, Paris 2 November 20or. Paris: UNESCO General Conference.

Valderama, F. (I995). A History of UNESCO. Paris: UNESCO Publishing.

Vergo, P. (Ed.). (I989). The New Museology. London: Reaktion Books.

Wagner, P. (2008). Modernity as experience and interpretation: A new sociology of modernity. London: Polity Press.

Wong, L. E. (2008). Relocating East and West: UNESCO's Major project on the mutual appreciation of Eastern and Western cultural values. Journal of World History, I9 (3), 349-374. 